\title{
Designing of an off-grid Photovoltaic system with battery storage for remote location
}

\author{
Diseño de un Sistema Fotovoltaico Aislado con Almacenamiento de Batería Para \\ Ubicación Remota
}

\author{
Asad A. Naqvi ${ }^{1^{*}}$ ｜ Talha Bin Nadeem ${ }^{1^{*}}$ ｜ Ahsan Ahmed ${ }^{1 *}$ ～Asad \\ Ali Zaidi ${ }^{2 \dagger}$
}

${ }^{1}$ Department of Mechanical Engineering, NED University of Engineering and Technology, Pakistan

${ }^{2}$ School of Computing Engineering and Digital Technology, Teeside University, Middlesbrough, Tees Valley, United Kingdom.

Correspondence

Asad A. Naqvi

Email: asadakhter@neduet.edu.pk

\section{Cc) creative}

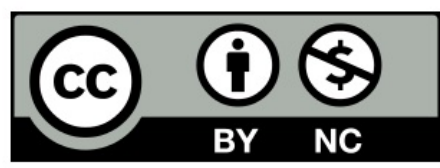

Abstract. Off-grid Photovoltaic (PV) system along with battery storage is very effective solution for electrification in remote areas. However, battery capacity selection is the most challenging task in system designing. In this study, an off-grid PV system along with battery storage is designed for the remote area of Karachi, Pakistan. The system is designed by considering the maximum energy requirement in summer season. The battery storage is selected to fulfill the energy demand during the night and cloudy seasons. On the basis of load, a total of $6 \mathrm{~kW}$ system is required to fulfill the energy demand. For such system, 925 Ah of battery is required to meet the energy requirement for a day in absence of solar irradiation. A regression-based correlation between battery capacity and energy demand is prepared for suitable battery sizing using Minitab. An economic analysis of the project is also carried out from which a net present value and simple payback are determined as USD 10,348 and 3 years, respectively. The environmental benefits are also been determined. It is found that the system will reduce around 7.32 tons of $\mathrm{CO}_{2}$ per annum which corresponds to the 183.69 tons of $\mathrm{CO}_{2}$ not produced in the entire project life.

Keywords: Off-grid PV system, battery storage, solar energy, economic analysis, regression correlation

Editors: Robert Paul Salazar

How to cite: Asad A. Naqvi, Talha Bin Nadeem, Ahsan Ahmed, S. \& Asad Ali Zaidi, Designing of an off-grid Photovoltaic system with battery storage for remote location, TECCIENCIA, Vol. 16, No. 31, 15-28, 2021

DOI:http://dx.doi.org/10.18180/tecciencia.2021.31.2

\section{RESUMEN}

El sistema fotovoltaico (PV) sin red junto con el almacenamiento de baterías son una solución muy eficaz para la electrificación en áreas remotas. Sin embargo, la selección de la capacidad de la batería es la tarea más desafiante en el diseño de sistemas. En este estudio, se diseñó un sistema fotovoltaico sin conexión a la red junto con el almacenamiento de baterías para el área remota de Karachi, Pakistán. El sistema está diseñado considerando el requerimiento máximo de energía en la temporada de verano. El almacenamiento de la batería se selecciona para satisfacer la demanda de energía durante la noche y las estaciones nubladas. Sobre la base de la carga, se requiere un sistema total de $6 k W$ para satisfacer la demanda de energía. Para tal

*Equally contributing authors. 
sistema, se requieren $925 \mathrm{~A} h$ de batería para cumplir con el requisito de energía durante un día en ausencia de irradiación solar. Se prepara una correlación basada en regresión entre la capacidad de la batería y la demanda de energía para el tamaño adecuado de la batería usando Minitab. También se realiza un análisis económico del proyecto a partir del cual se determina un valor actual neto y una recuperación simple de USD10.348 y 3 años, respectivamente. También se determinaron los beneficios ambientales. Se encuentra que el sistema reducirá alrededor de 7.32 toneladas de $\mathrm{CO}_{2}$ por año, lo que corresponde a las 183.69 toneladas de $\mathrm{CO}_{2}$ no producidas en toda la vida del proyecto.

Palabras clave: Sistema fotovoltaico sin red, almacenamiento de baterías, energía solar, análisis económico, correlación de regresión.

\section{| Nomenclature}

- AC: Alternating Current

- Ah: Ampere hour

- AS: Annual savings from the project

- BS: Battery Storage

- CC: Cost of the equipment which needs to be changed after the component life

- $\mathrm{Cl}$ : Capital investment of the project

- DC: Direct Current

- DR: Derating

- $E_{A C}:$ AC Energy

- Edel: Actual Energy Delivered in kWh

- $E_{D C}$ : DC Energy

- FOC: Factor of conversion

- GHGs: Green House Gases

- $h_{\text {peak }}$ : Peak sun hours

- i: interest rate

- IR: Rated current of a PV module in Amperes

- MDOD: Maximum Depth of Discharge

- $\quad \mathrm{N}$ : Life of the project

- ni: Life of a particular component

- NPV: Net Present Value

- $N_{\text {storage }}:$ Number of storage days

- Pdc: DC Power in kW

- PV: Photovoltaic

- $V_{N B}$ : Battery nominal voltage

- VR: Rated voltage of a PV module in Volts

- $V_{\text {sys }}$ : System Voltage

- $\eta_{c o l}$ : Columbic Efficiency

- $\eta_{s y s}:$ System efficiency

\section{1 | INTRODUCTION}

Energy requirement across the globe is increasing day by day. Developing countries are struggling in progress due to a shortage of energy. In Pakistan, the shortfall is around 4.5 GW since the last few years [1] due to which the growth of Pakistan in all the fields is very slow. There are many losses associated in the transmission and distribution systems [2] due to which the generated quantity is unable to utilize properly especially in those areas where line losses are high. There are also certain areas in Pakistan where there is unavailability of the grid. Around 50 million people in Pakistan are living without electrical connection [3]. In such areas, the utilization 
of solar energy for the fulfillment of electrical demands of the local community is one of the best solutions $[4,5,6]$. A lot of work on potential, advantages and utilization of solar energy in Pakistan has been done in the recent past $[7,8,9,10,11,12,13]$.

Solar energy can be used directly as electrical energy using PV systems or can be used for steam generation in traditional power plants through thermal collectors $[14,15]$. The use of thermal collector is quite complex [14] while the use of PV system for fulfillment of electricity requirement is simple and cost-effective options. The PV systems are classified as on grid and off-grid system. On-grid system which are also known as grid-tied systems are those where PV system are used along with grid [16]. PV system is used to fulfill the energy demand of the house during day time while at night grid electricity is used. While in off-grid system, the PV system is used to fulfill the energy requirement in day time and during night time the batteries are used for meeting the electricity demand. The batteries are charged through the PV system. So, the portion of electricity from PV utilizes in running the electrical appliances and the other portion of electricity is consumed to charge the batteries for night time or during no sun conditions. In remote locations of Pakistan, off-grid PV system is widely adaptable and acceptable. There are number of researchers who have worked on the feasibility study of the off-grid PV system for fulfillment of electricity demand. Ali et al. [17] has worked for the feasibility study of remote location in Karachi and found that for 100 watts daily demand the system requires low investment cost with an acceptable payback period of 2.5 years only. Shehzad et al. [18] has conducted the techno-economic analysis of solar biomass off-grid for electricity production in rural areas of Pakistan using HOMER software and found that the system has a payback period of around 9.5 years. Irfan et al. [19] has reported that for a province of Punjab, Pakistan the electricity generation cost from off-grid PV system will be USD 0.047 per kWh and also reported that if all the people in Punjab adapt PV system, then it will result in 617,020 metric tons of $\mathrm{CO}_{2}$ could be reduced annually. Xu et al. [20] has determined that the utilization of off-grid PV system in the province of Sindh is economically as well as environmentally beneficial and it can fulfill the energy requirement of the remote areas. Shah et al. [21] has also reported that off-grid PV system is technically as well as economically viable for Baluchistan province. Ghafoor and Munir [22] has presented the design for off-grid PV system for the electrification of house in Faisalabad, Pakistan and has reported that the system is able to meet the electricity demand of the house. They have also performed the economic analysis and have reported that the system is economically beneficial with life cycle cost of USD 2992. Merei et al. [23] has modeled stand-alone hybrid energy system which involves PV, wind energy, diesel generator and batteries for backup power and has reported that the system has economic and ecological benefits. Rehman et al. [24] has conducted a study on hybrid system consist of PV, wind, diesel generator and batteries for electrification of residential building and found that the system will result in around $69 \%$ of reduction in greenhouse gases of local atmosphere. Kamal et al. [25] has analyzed the hybrid system consist of PV, micro hydel, biomass and batteries for electrification of rural areas in Pakistan and found that the system is technically as well as economically viable.

In the light of above-mentioned literature, off-grid PV system is one of the best solutions for the electrification of remote areas where the grid is not available. However, no significant work has been reported yet which includes the combination of battery capacity estimation and emission analysis. In this research, an offgrid system is proposed for the electrification of residential building located in the remote location of Karachi, Pakistan. The technical, economic and environmental analyses of the system are carried out to check the feasibility of the system for residential building application. A regression equation for battery capacity is developed using Minitab, to predict the battery capacity on the basis of energy requirement.

\section{2 | SYSTEM DESCRIPTION}

The schematic diagram of the off-grid PV system is presented in Fig 1. Solar radiations fall on the PV panels which are being converted into DC electricity. The DC electricity from PV is stabilized through the charge controller to protect the battery from overcharging. When the electricity production from PV is higher than 
the demand, additional energy is stored by the battery which is utilized by the appliances when energy demand is higher than energy production from PV. Mostly, the appliances in any residential or commercial building require $A C$ electricity so the inverter is installed to convert the $D C$ electricity into $A C$ electricity.

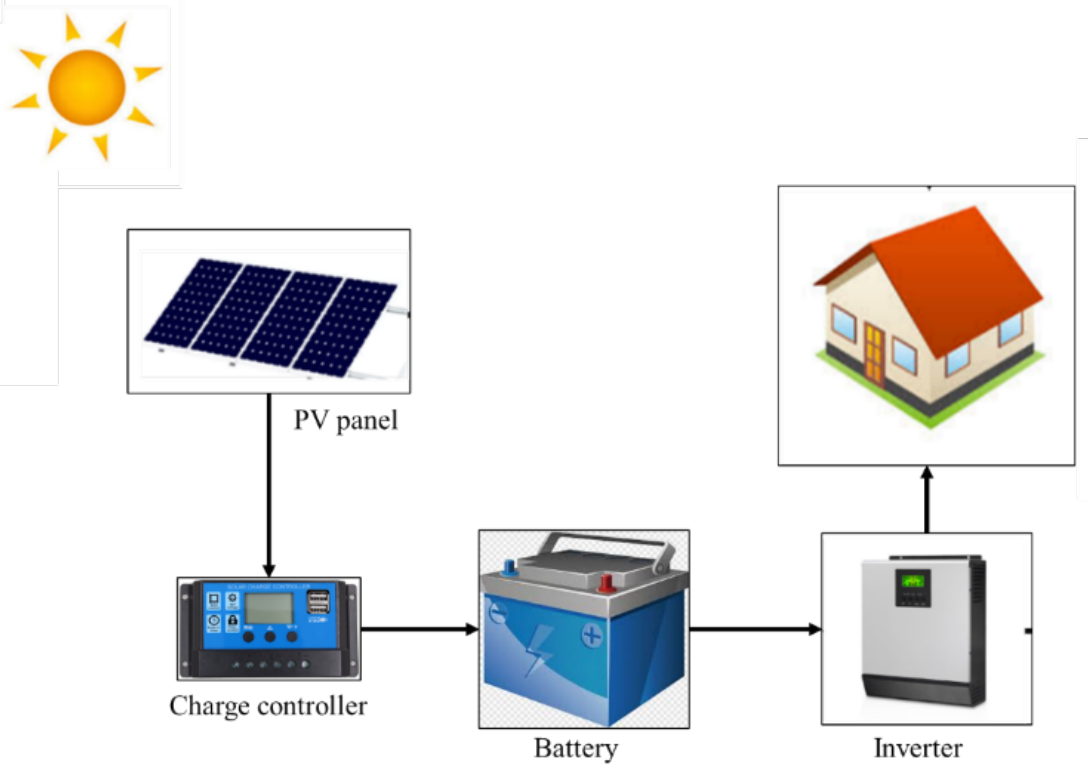

FIG. 1 Schematic diagram of off-grid PV system.

\section{3 | METHODOLOGY}

The study is conducted for a residential building located in remote area of Karachi having a latitude $24.8607^{\circ} \mathrm{N}$, and longitude $67.0011^{\circ} \mathrm{E}$. Most of the times, the weather is hot and humid with average ambient temperature of $27^{\circ} \mathrm{C}^{1}$. The daily electrical requirement of the house during summer days is presented in Table. 1 and Fig. 2.

TAB LE 1 Energy consumption by the appliances during summers.

\begin{tabular}{|l|c|c|c|c|c|}
\hline Appliances & Power rating (Watts) & Quantity & \multicolumn{1}{|c|}{ Total power (Watts) } & No. of hrs & Energy (kWh) \\
\hline LED Bulb & 10 & 30 & 300 & 7 & 2.1 \\
\hline Air Conditioners & 900 & 2 & 1800 & 6 & 10.8 \\
\hline Fridge & 90 & 2 & 180 & 24 & 4.32 \\
\hline Electric iron & 1000 & 1 & 1000 & 0.5 & 0.5 \\
\hline Ceiling fan & 80 & 10 & 800 & 7 & 5.6 \\
\hline Water Pump & 750 & 1 & 750 & 0.5 & 0.375 \\
\hline Ceiling fan & 80 & 10 & 800 & 7 & 5.6 \\
\hline Washing machine & 900 & 1 & 900 & 1 & 0.9 \\
\hline Total & & & & & 24.595 \\
\hline
\end{tabular}

The total electrical energy requirement during summer days is around $24.6 \mathrm{kWh}$ per day. The electrical energy requirement is calculated by using the load calculator given by the local electricity supplier of Karachi . From Fig. 2, the major portion of electricity is consumed by air conditioners and ceiling fans due to hot weather of Karachi ${ }^{2}$. Around $67 \%$ of energy is consumed by both air conditioners and fans. While the remaining $33 \%$ is

\footnotetext{
${ }^{1}$ Monthly weather forecast and climate Karachi, Pakistan. [Online]. Website: https://www.weather-atlas.com/en/pakistan/karachi-climate [Accessed 10 March 2021]

2 Electric load calculator [Online]. Website: https://www.ke.com.pk/sustainability/energy-conservation/ec-calculator/ [Accessed 15 March 2021].
} 
used by other appliances. The day and night requirement of electricity is presented in Fig. 3. During summer nights, the average electricity needed is around $13.56 \mathrm{kWh}$ while during the day time the energy requirement is $11.035 \mathrm{kWh}$. Fridge needs be run throughout the day while electric iron, water pump and washing machine run only during day time. LED bulbs, ceiling fans and air conditioners run during day time as well as during night time. The month wise electricity demand of the residential is presented in Fig. 4. It is evident that maximum electricity requirement is in the month of May due to summer season as most of the air conditioners and ceiling fans needs to be run which require around $67 \%$ of the total energy demand. The winter season in Karachi is not harsh so there is no requirement of heating hence it results in very low amount of electricity in the months of winter as December and January. The electricity produced by PV system is DC electrical energy while the

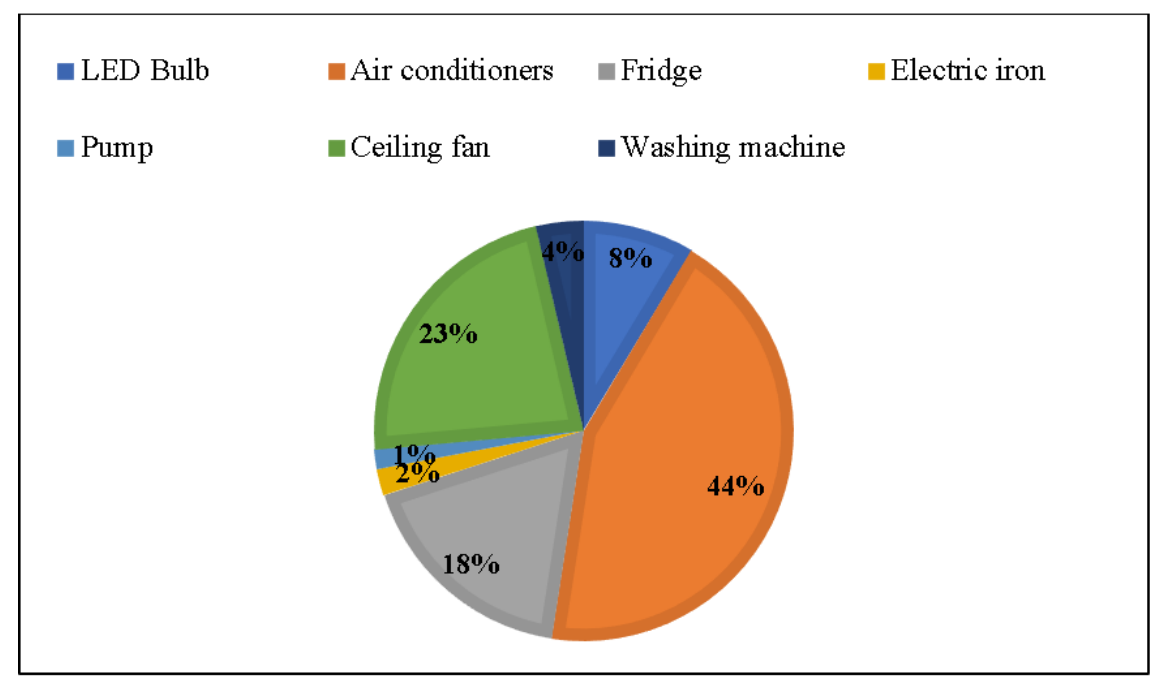

FIG. 2 Electricity consumption during summer days.

electrical energy required by the appliances is $A C$ in nature. The DC energy required by the appliances can be calculated as:

$$
E_{D C}=E_{A C} \times F O C
$$

FOC takes into accounts the losses due to inverter, module mismatch, soil derating and temperature derating of the PV module. Normally, the losses are around 30\% [26]. It means that FOC of is around 1.3. In general,

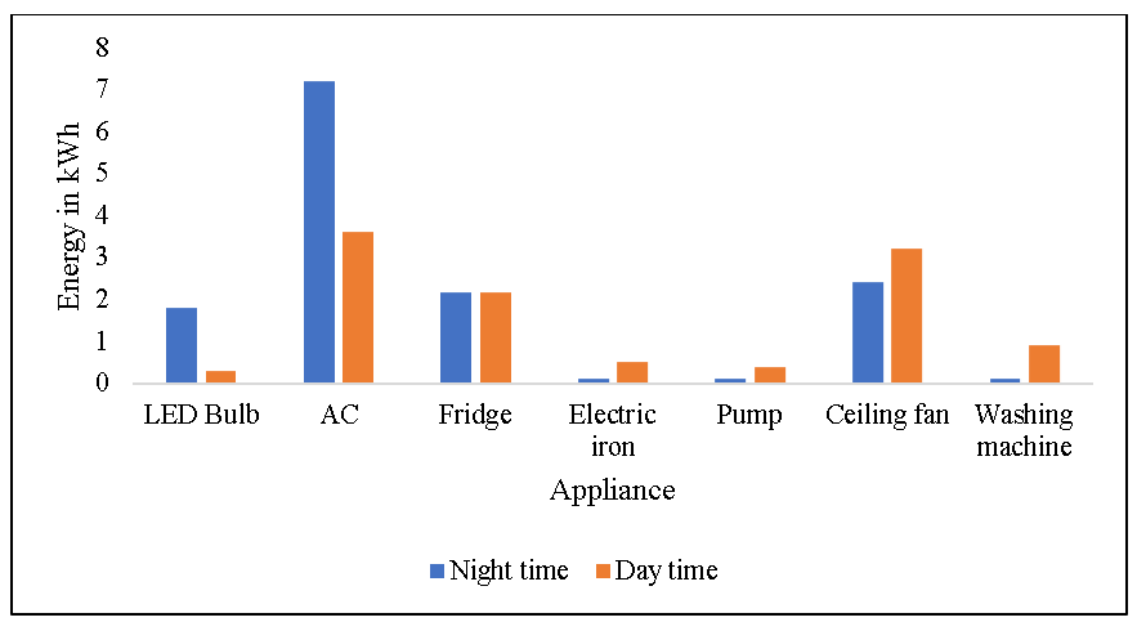

FIG. 3 Electrical consumption during night and day time. 
the PV systems are installed on the basis of DC power requirement. The DC power rating of the system will be [26]

$$
P_{d c}=\frac{E_{D C}}{h_{p e a k}} .
$$

The battery capacity is normally given as Ah. So, the Ah requirement by the load can be calculated as

$$
\text { Daily Ah to load }=\frac{E_{D C}}{V_{s y s}} \text {. }
$$

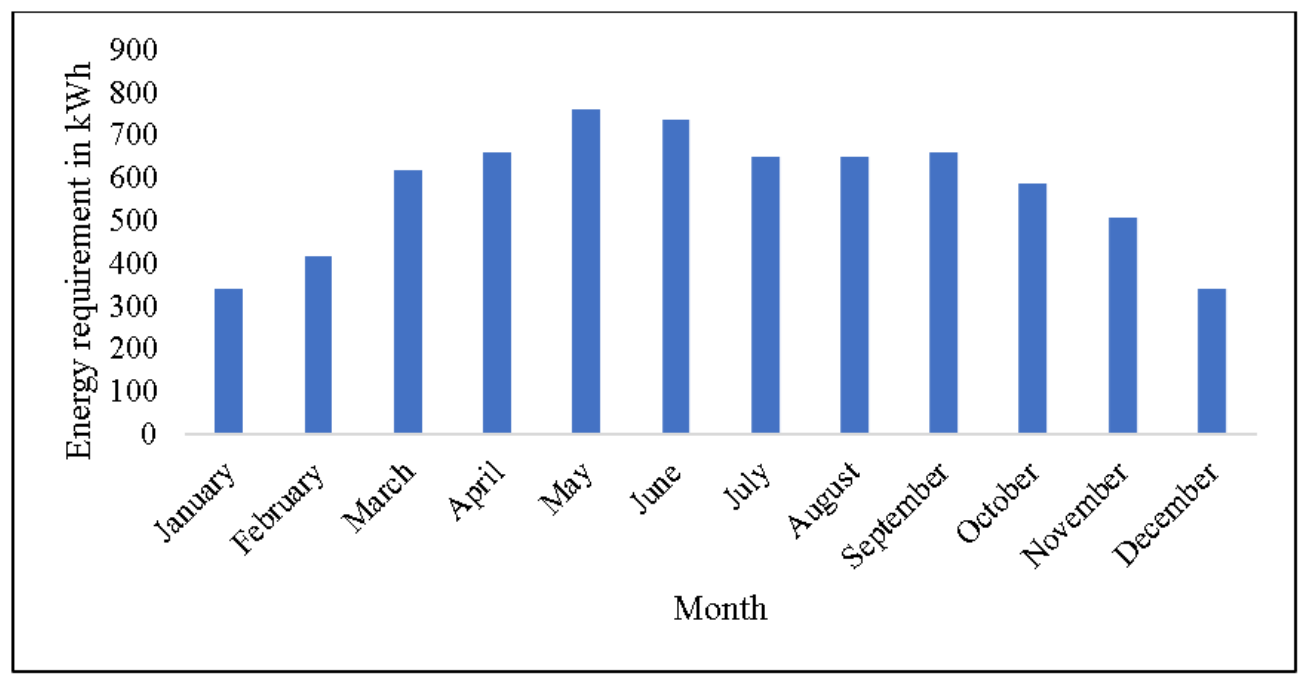

FIG. 4 Monthly energy requirement of the building.

The battery storage required for the required load can be calculated by [21]

$$
B S=\left(\text { Ah to load } \times N_{\text {storage }}\right) /\left(M D O D \times \eta_{\text {col }}\right)
$$

$$
\text { Number of batteries in series }=\frac{V_{\text {sys }}}{V_{N B}}
$$

$$
\text { Number of parallel battery strings }=\frac{\text { Ah to load }}{\text { Nominal battery capacity in Ah }}
$$

The Ah produced by the single PV module is [26] Ah by

$$
P V=I_{R} \times h_{\text {peak }} \times D R \times \eta_{c o l}
$$

The total number of PV module string in parallel [26]

$$
\text { Number of PV strings in parallel }=\frac{\text { Ah to load }}{\text { Ah by single PV }}
$$


The total number of PV modules in series

$$
\text { Number of } \mathrm{PV} \text { modules in series }=\frac{V_{\text {sys }}}{V_{R}}
$$

The actual energy delivered by the PV system can be estimated as [26]

$$
E_{d e l}=P_{d c} \times h_{\text {peak }} \times \eta_{s y s}
$$

The specifications of PV module, inverter and battery is given in Tables. 2, 3 and 4 respectively. The PV module is selected of Canadian solar brand, inverter is of homage brand and AGS battery is selected because of easily available in the local market. To check the economic benefits, NPV needs to be determined. The NPV of the project can be calculated by [27]

$$
N P V=-C I+A S\left[\frac{(i+1)^{2}-1}{i(i+1)^{n}}\right]-\sum_{j=1}^{n_{j}} C \operatorname{Cost}\left(\frac{1}{i+1}\right)^{n_{j}}
$$

Here $\mathrm{Cl}$ is the capital investment of the project, AS is the net annual savings from the project, CC cost is the cost of the equipment which needs to be changed after the component life, $i$ is the interest rate, $\mathrm{n}$ is the life of the project and $n_{j}$ is the life a particular component.

TABLE 2 Specifications of PV module ${ }^{a}$.

\begin{tabular}{|l|c|}
\hline Rated power & $250 \mathrm{~W}$ \\
\hline Rated current & $8.3 \mathrm{~A}$ \\
\hline Rated voltage & $30.1 \mathrm{~V}$ \\
\hline Short circuit current & $8.87 \mathrm{~A}$ \\
\hline Open circuit voltage & $37.2 \mathrm{~V}$ \\
\hline Efficiency & $15.54 \%$ \\
\hline NOCT & $45^{\circ} \mathrm{C}$ \\
\hline
\end{tabular}

${ }^{a}$ Specifications of Canadian solar PV module. [Online]. Website: https://www.zonnepanelen.net/nl/pdf/panels/CS6P-Pen.pdf [Accessed15March2021]

The environmental impact of the system has also been checked. When the electricity is produced by conventional power plants then there will be a huge amount of GHGs production. On average 0.473 tons of $\mathrm{CO}_{2}$ per MWh, $0.014 \mathrm{~kg}$ of $\mathrm{CH}_{4}$ per $\mathrm{MWh}$ and $0.002 \mathrm{~kg}$ of $\mathrm{N}_{2} \mathrm{O}$ per MWh is produced through conventional power plants [28].

TAB LE 3 Specification of Inverter ${ }^{a}$.

TABLE 4 Specification of the battery ${ }^{a}$.

\begin{tabular}{|l|c|}
\hline Rated power & $5 \mathrm{~kW}$ \\
\hline Input voltage DC & $48 \mathrm{~V}$ \\
\hline Output voltage AC & $230 \mathrm{~V}$ \\
\hline Efficiency & $97 \%$ \\
\hline
\end{tabular}

\begin{tabular}{|l|c|}
\hline Battery type & Lead Acid \\
\hline Capacity @ 20 hrs. & 200 Ah \\
\hline Capacity @ 5 hrs. & 160 Ah \\
\hline Plate Quantity & 23 \\
\hline
\end{tabular}

\footnotetext{
${ }^{a}$ Specifications of Homage inverter. [Online]. Website: https://homage.pk/hvs-5014-vertex- $\quad$ Specifications of AGS battery. [Online]. Website: https://abl.atlas.pk/product/dc-110inverter/ [Accessed 15 March 2021] 2/ [Accessed 15 March 2021]
} 


\section{4 | RESULTS AND DISCUSSIONS}

The site selected for the study is located in Karachi. The PV panels are assumed to be installed at angle of around $25^{\circ}$ approximately equal to a latitude of Karachi in order to capture the maximum solar radiations. The monthly average daily solar radiations on tilted surface are estimated from the models presented by Ahmed and Ulfat [29] and Lui and Jordan [30].

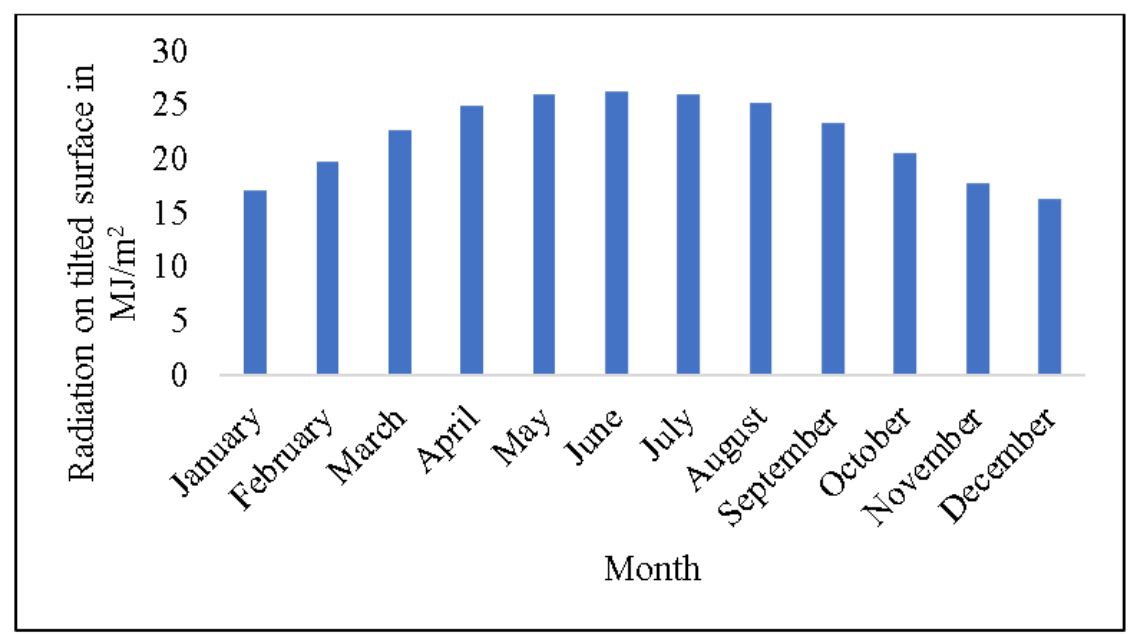

FIG. 5 Monthly average daily total radiation on tilted surface.

The radiation available on a tilted surface is presented in Fig. 5. From where, it is clear that the solar energy potential in Karachi is very good and a considerable amount of energy being extracted by the solar energy. On average, around $250 \mathrm{MJ} / \mathrm{m}^{2}$ of solar energy is available on a tilted surface of $25^{\circ}$. The maximum radiation is available in the month of May and June because of longer days while the minimum is available in the month of December because of shorter days. On average around $18 \mathrm{MJ} / \mathrm{m}^{2}$ energy is available on daily basis. The available solar energy can be directly converted into electrical energy using PV or it can be converted into high quality heat by using concentrated solar thermal collector.

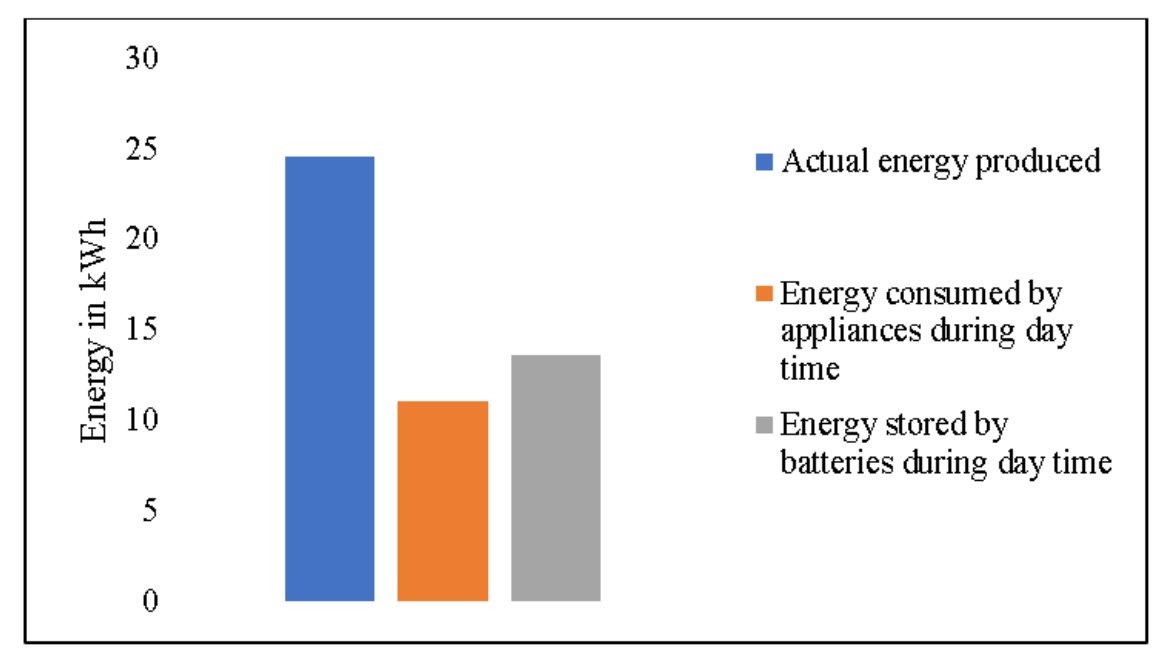

FIG. 6 Monthly average daily total radiation on tilted surface.

The load for the residential building was analyzed by the equations mentioned in the previous section. The system designing was done by considering the load requirement of summer season because the system should 
be capable to meet the energy requirement of the residential building. During summer season, the average energy requirement is around $24.6 \mathrm{kWh}$. The DC energy demand for the residential building was determined by equation 1. DC energy demand was determined because the electricity produced by PV system is DC in nature. The Factor of conversion was taken to be 1.3 because when DC electricity is converted into AC electricity, losses occurred. Also, in PV system there are losses due to inverter, soil, mismatch and temperature derating. Keeping all the losses, FOC was assumed to be 1.3, means there are around $30 \%$ losses in PV operation. After, determining the DC energy requirement, the second step was the determination of the size of PV system, means the wattage of the PV system because every electrical energy generation setup is installed on the basis of power. The DC power rating of the system was determined by equation. The peak sun hours for Karachi were taken to be 5.4 hours [31]. The peak sun hour is the interpretation of number of hours required for the extraction of total energy if the insolation is constantly maintained at $1000 \mathrm{~W} / \mathrm{m} 2$. It is an important parameter and is required in PV system designing either on-grid or off-grid system. The electrical energy generated from the PV system is required to store because of night time energy requirement. The part of the energy from PV will be utilize to fulfil the energy demand of the house while the remaining portion will be stored in the battery. The battery capacity is one of the most important part of the PV system designing that what must be the minimum battery capacity to run the load for a given time. The battery capacity was found from equation 4 . The battery capacity depends upon the Ah requirement of the load. The Ah requirement was found from equation 3 . The system voltage was taken to be $48 \mathrm{~V}$ as input requirement of the inverter. There are different system voltages available in literature like $12 \mathrm{~V}, 24 \mathrm{~V}$ and $48 \mathrm{~V}$. The $48 \mathrm{~V}$ system is selected because at high voltage, current reduces which means low current losses or low power loss. The coulomb efficiency and MDOD was taken to be $90 \%$ and 0.8 respectively [26]. The summary of the system design is presented in Table. 5. The total system will be of $6 \mathrm{~kW}$, which requires 42 panels each of $250 \mathrm{~W}, 24$ batteries each of $165 \mathrm{Ah}$ and $12 \mathrm{~V}$ for energy storage for night time operation and 2 inverters for DC to AC conversion each of $3000 \mathrm{~W}$. The battery will save energy for 1 day. More number of batteries will be required, if the energy storage for more than 1 day is required.

TABLE 5 Specification of the system to be installed.

\begin{tabular}{|l|c|}
\hline DC energy required & $31.98 \mathrm{kWh}$ \\
\hline Total DC power Rating & $6 \mathrm{~kW}$ \\
\hline Ah required by load & $666.25 \mathrm{Ah}$ \\
\hline Battery storage for 1 day backup & $925 \mathrm{Ah}$ \\
\hline No. of batteries in parallel & 6 \\
\hline No. of batteries in series & 4 \\
\hline Total number of batteries & 24 \\
\hline Ah per string & $32 \mathrm{Ah}$ \\
\hline No. of strings in parallel & 21 \\
\hline No. of panels in series & 2 \\
\hline Total number of PV & 42 \\
\hline
\end{tabular}

The total energy delivered by the system was determined by equation 10 . The energy will be produced only in day time. The total energy from the PV, energy utilizes by electrical appliances during day time and energy store by the batteries is presented in Fig. 6. Total energy from the system was found to be around 25 $\mathrm{kWh}$ which is enough to fulfil the energy demand of the building. Out of total energy, $11.5 \mathrm{kWh}$ energy will be used to fulfil the energy requirement of the house while the rest of the around $13.5 \mathrm{kWh}$ energy will be store by the batteries during night time operations. It means that the system is able to meet the power requirement during day time as well as during night time. It is able to store energy for 1 day.

The battery selection is the major problem in the designing of the off-grid system. Sometimes, under capacity battery is selected which is responsible of inappropriate working of the system during night times or cloudy days and some times over capacity is selected which results in high cost of the system. The battery with optimum capacity selection is very important. Keeping in view, a regression-based equation for the selection 
of battery capacity with respect to the energy demand is developed using Minitab. The equation is valid for 1 day storage and for $48 \mathrm{~V}$ system. The results of the regression are presented in Fig. 7. The regression equation formed has Coefficient of Determination $\left(R^{2}\right)$ value of $99.8 \%$ which shows that proposed regression model suits best with the data points.

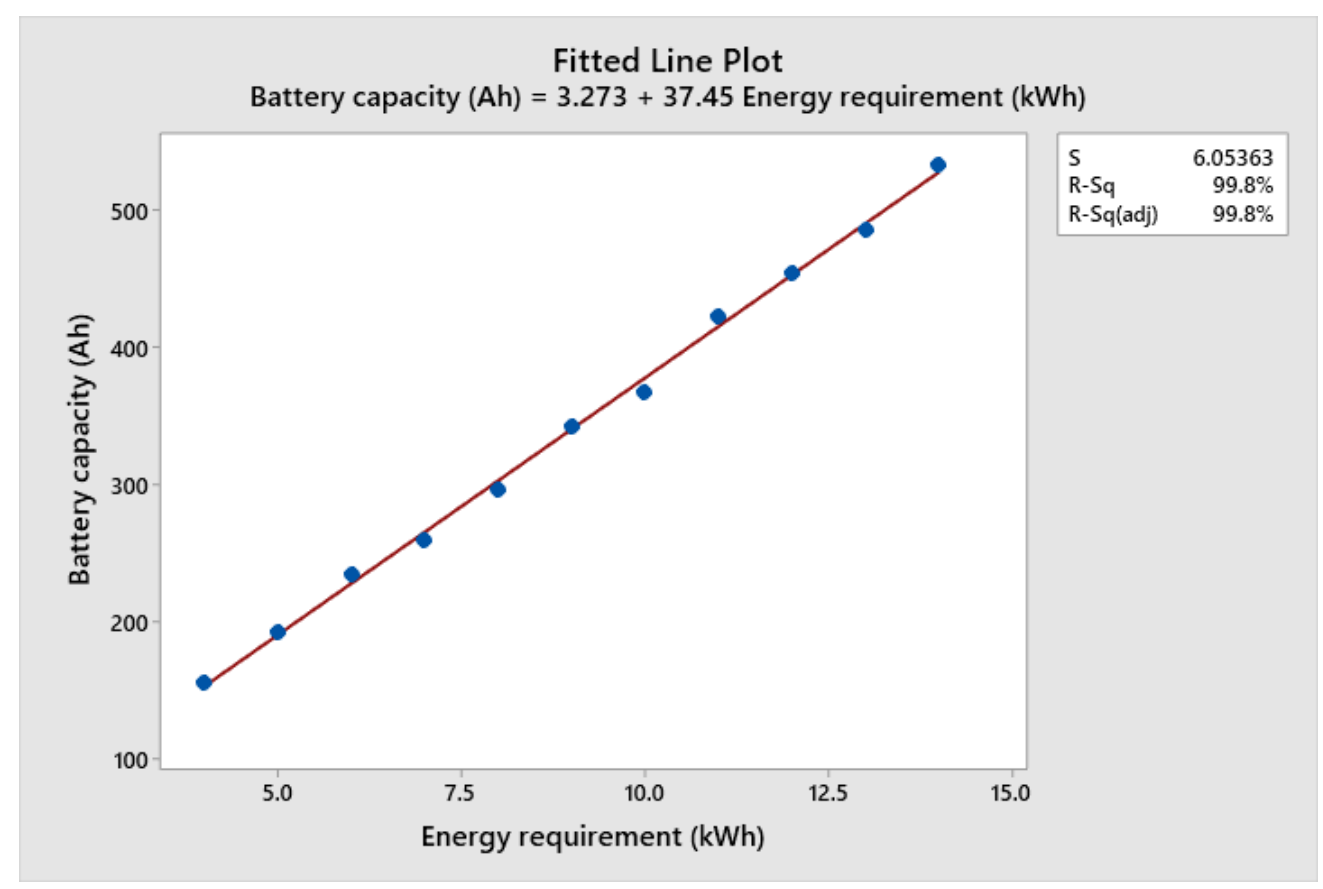

FIG. 7 Regression correlation between energy demand and battery capacity.

Technically, the system is able to meet the energy requirement of the load. But for the selection of any project, economics play a very vital role. The economic analysis of the system is also done to check the economic benefits of the system. The NPV of the system of the system is found by equation 11. The discount rate was taken to be $7 \%$ of Pakistan ${ }^{3}$ and the project life was taken to be 25 years [32], inverter life was taken to be 15 years [33] and battery life was taken to be 5 years [19]. The electricity rate from the local grid is USD $0.13 / \mathrm{kWh}$. The cost breakdown of all the components is presented in Table. 6.

TABLE 6 System cost breakup .

\begin{tabular}{|l|c|}
\hline Description Cost in USD PV panels & 1,650 \\
\hline Inverters & 750 \\
\hline Batteries & 3,930 \\
\hline Charge controller & 15 \\
\hline Miscellaneous & 350 \\
\hline Total Cost & 6,695 \\
\hline
\end{tabular}

TABLE 7 GHG reduction in entire life of 25 years.

\begin{tabular}{|c|c|}
\hline GHG & Quantity \\
\hline $\mathrm{CO}_{2}$ & 183.69 tons \\
\hline $\mathrm{CH}_{4}$ & $5.37 \mathrm{~kg}$ \\
\hline $\mathrm{N}_{2} \mathrm{O}$ & $0.94 \mathrm{~kg}$ \\
\hline
\end{tabular}

Utilizing the cost mentioned in Table. 6, the NPV of the system from equation 11 was found to be USD 10348. NPV of the system is positive so it means that the system is economically beneficial. The payback period of the system is also found. The cumulative cash flow of the system is presented in Fig. 8 and from that figure it is evident that payback period of the system is around 3 years which means that it will return all the investment in just 3 years. Inverter has a life of 15 years which means that inverter needs to be change after 15 years and battery has a life of 5 years which means that after every 5 years, batteries need to be changed. The system will require investment in the 5 th, 10th, 15th and 20th year of the project life but the investment

3 Interest rate of Pakistan. [Online]. Website: https://tradingeconomics.com/pakistan/interest-rate [Accessed 15 March 2021] 
will not create any negative impact on the overall project. The project is beneficial for the consumer technically as well as economically.

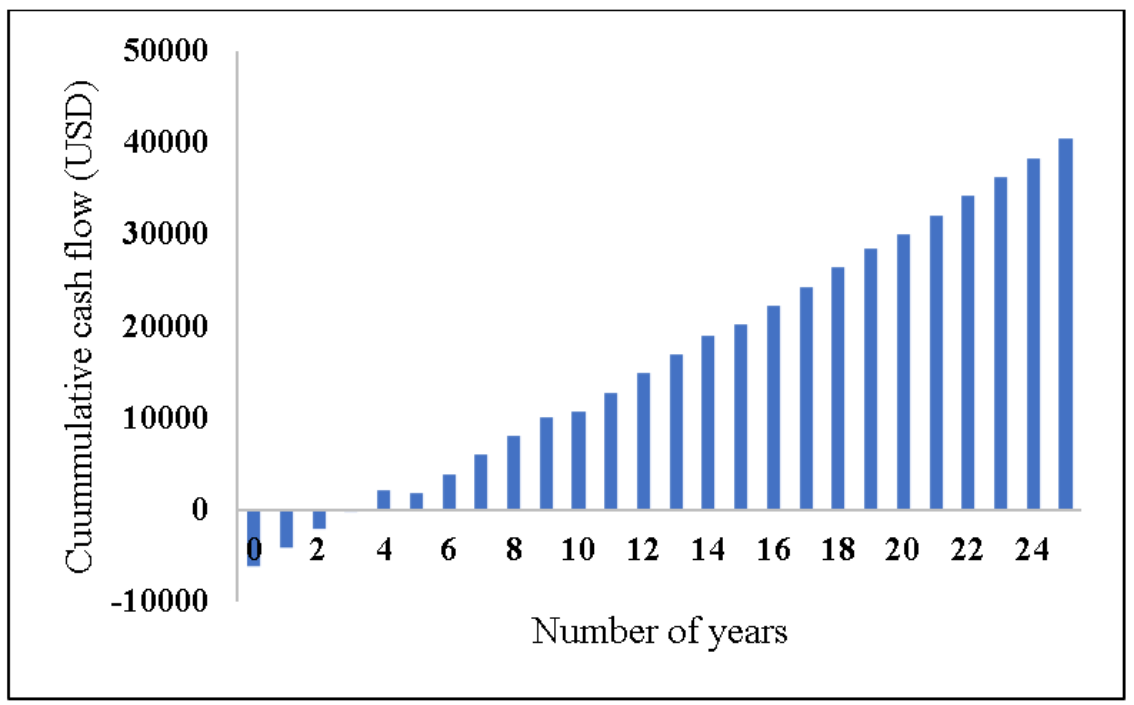

FIG. 8 Cumulative cash flow diagram.

To check the impacts of the system on environment, environmental analysis of the system is done. The impacts of the system on environment are found to be in favor. The system is able to produce electricity around $15.52 \mathrm{MWh}$ in a year which means that in the total project life of 25 years it will produce around $388 \mathrm{MWh}$ of electricity. This electricity obtained from the system is clean and green and no production of GHGs will occur. If $388 \mathrm{MWh}$ of electricity is generated through conventional power plants then a very huge amount of GHGs will be produced and will release in the environment. If $25 \mathrm{kWh}$ per day of electricity which corresponds to the $750 \mathrm{kWh}$ of electricity per month is produced through conventional power plants, then on average 0.61 tons of $\mathrm{CO}_{2}$ will be produced in every month as shown in Fig. 9 which corresponds to the 7.32 tons of $\mathrm{CO}_{2}$ per annum. Since, in this study there is no utilization of conventional power plants for electricity generation so there is no production of GHG gases.

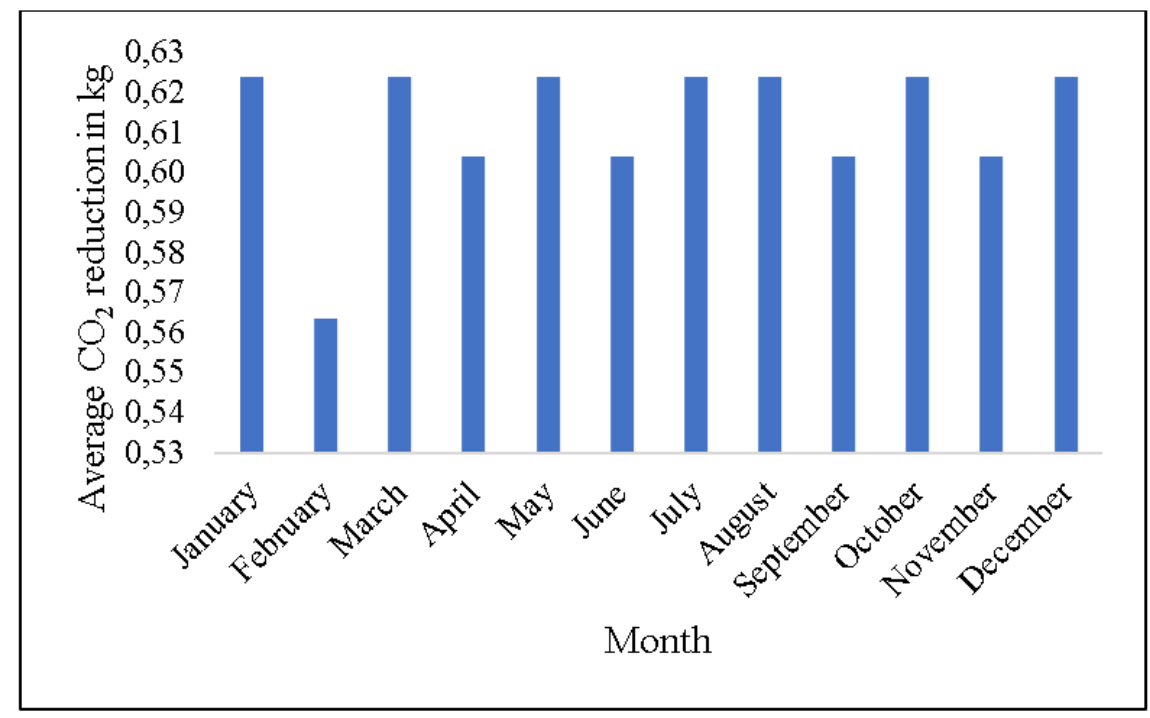

FIG. $9 \mathrm{CO}_{2}$ reduction in every month. 
The amount of $\mathrm{CO}_{2}, \mathrm{CH}_{4}$ and $\mathrm{N}_{2} \mathrm{O}$ not produced in the entire life cycle of the project is presented in Table. 7. It can easily be concluded that around 183.69 tons of $\mathrm{CO}_{2}$ will be produced if $388 \mathrm{MWh}$ of electricity is produced through conventional power plants. Since $388 \mathrm{MWh}$ of electricity is produced through PV system so it means it is able to save the environment by not producing around 183.69 tons of $\mathrm{CO}_{2}, 5.37 \mathrm{~kg}$ of $\mathrm{CH}_{4}$ and $0.94 \mathrm{~kg}$ of $\mathrm{N}_{2} \mathrm{O}$.

\section{5 | CONCLUSIONS}

The off-grid PV system along with battery storage for the residential building was designed according to the energy requirement during the summers. The maximum energy requirement was found to be around $25 \mathrm{kWh}$. To meet the energy requirement, total DC power of the system was found to be $6 \mathrm{~kW}$. Total battery capacity for the system was found to be around $925 \mathrm{Ah}$. The system was found to run the appliances through PV during day time and through batteries during night time. The battery selection is the most critical step in the designing of the off-grid PV system. A regression correlation for the estimation of battery capacity as per the energy requirement is proposed. The correlation is valid only for $48 \mathrm{~V}$ system voltage and 1 day storage capacity. The correlation is able to estimate approximate value of battery capacity required. To check the economic viability of the project, economic analysis has also been done and it was found that the project is economically viable with NPV of USD 10348 and payback period of 3 years. It means that the system will return its investment in just 3 years. The batteries are need to be replaced after every 5 years but it will create no negative impacts on the project. The system was also found to be environment friendly as it was found that around 183.69 tons of $\mathrm{CO}_{2}$ production will be reduced by fulfilling the energy requirement through the cleaner mechanism. The study can be applied to any area having environmental condition similar to Karachi. The effects of using biomass for backup power can be checked and accepted by the remote areas.

\section{Acknowledgments}

\section{References}

[1] K. Latif, M. Raza, S. Adil, and R. Kouser, "Analysis of energy crisis, energy security and potential of renewable energy: Evidence from pakistan," Journal of Accounting and Finance in Emerging Economies, vol. 6, no. 2518. DOI: $10.26710 /$ jbsee.v6i1.1072

[2] K. Ullah, "Electricity infrastructure in pakistan: an overview," International Journal of Energy, Information and Communications, vol. 4, p. 11-26.

[3] H. Samad and F. Zhang, "Electrification and household welfare: Evidence from pakistan," Electrification and Household Welfare: Evidence from Pakistan. DOI: 10.1596/1813-9450-8582

[4] J. Falk, A. Nedjalkov, M. Angelmahr, and W. Schade, "Applying lithium-ion second life batteries for off-grid solar powered system-a socio-economic case study for rural development," Zeitschrift Für Energiewirtschaft, vol. 44, p. 47-60. DOI: 10.1007/s12398-020-00273-x

[5] A. Ayik, N. ljumba, C. Kabiri, and P. Goffin, "Selection of off-grid renewable energy systems using analytic hierarchy process: Case of south sudan," IEEE PES/IAS PowerAfrica, PowerAfrica. DOI: 10.1109/ PowerAfrica49420.2020.9219858

[6] Z. Said, A. Mehmood, A. Waqas, A. Amine Hachicha, and R. Loni, "Central versus off-grid photovoltaic system, the optimum option for the domestic sector based on techno-economic-environmental assessment for united arab emirates," Sustainable Energy Technologies and Assessments, vol. 43, no. 100944. DOI: $10.1016 / j$. seta.2020.100944

[7] S. Adnan, A. Hayat Khan, S. Haider, and R. Mahmood, "Solar energy potential in pakistan," Journal of Renewable and Sustainable Energy, vol. 4. DOI: 10.1063/1.4712051 
[8] M. D. MK, S. S, A. AW, S. K, S. MY, and A. N, "Silicon back contact solar cell configuration: A pathway towards higher efficiency," Renewable and Sustainable Energy Reviews, vol. 60, p. 1516-32. DOI: 10.1016/ j.rser.2016.03.004

[9] M. Irfan, Z.-Y. Zhao, M. Ahmad, and M. Mukeshimana, "Solar energy development in pakistan: Barriers and policy recommendations," Sustainability, vol. 11, no. 1206. DOI: 10.3390/su11041206

[10] M. Irfan, Y. Hao, M. Ikram, H. Wu, R. Akram, and A. Rauf, "Assessment of the public acceptance and utilization of renewable energy in pakistan," Sustainable Production and Consumption, vol. 27, p. 312-24. DOI: $10.1016 /$ j.spc. 2020.10.031

[11] Y. Wang, L. Xu, and Y. Solangi, "Strategic renewable energy resources selection for pakistan: Based on swot-fuzzy ahp approach," Sustainable Cities and Society, vol. 52. DOI: 10.1016/j . scs . 2019.101861

[12] M. Kamran, M. Mudassar, M. Ahmed, SR, J. HS, H. FM, and M., "Socio-economic acceptance for standalone solar pv systems: Survey evidence from southern punjab, pakistan," International Journal of Renewable Energy Research, vol. 9, p. 301-8.

[13] W. The and W. Academy, "Economical benefits of integrating solar energy based n.d."

[14] J. A. WAB, "Solar engineering of thermal processes." DOI: 10.1016/s0272-2712(18) 30627-9

[15] A. V. A, H. JE, and L. A, "Comparison of thermal solar collector technologies and their applications," Tecciencia, vol. 8, p. 27-35. DOI: 10.18180/tecciencia.2013.15.3

[16] Y. Muñoz, V. Orlando, P. Gustavo, and V. Jairo, "Sizing and study of the energy production of a grid-tied photovoltaic system using pv syst software," Tecciencia, vol. 12, p. 27-32. DOI: 10.18180/tecciencia. 2017.22 .4

[17] M. Ali, M. Yamin, C. UF, and A.N., "A feasibility study: Off-grid photovoltaic solar power supply to the remote areas of pakistan," Pakistan Journal of Agricultural Sciences, vol. 57, p. 1279-86. DOI: 10.21162/ PAKJAS/20.468

[18] M. Shahzad, A. Zahid, T. Rashid, M. Rehan, M. Ali, and M. Ahmad, "Techno-economic feasibility analysis of a solar-biomass off grid system for the electrification of remote rural areas in pakistan using homer software," Renewable Energy, vol. 106, p. 264-73. DOI: 10.1016/j .renene.2017.01.033

[19] M. Irfan, Z. Zhao, M. Ahmad, and A. Rehman, "A techno-economic analysis of off-grid solar pv system: A case study for punjab province in pakistan," Processes, vol. 7, p. 1-14. DOI: 10.3390/pr7100708

[20] L. Xu, Y. Wang, Y. Solangi, H. Zameer, and S. Shah, "Off-grid solar pv power generation system in sindh, pakistan: A techno-economic feasibility analysis," Processes, vol. 7. DOI: 10.3390/pr7050308

[21] S. Shah, V. G. Das, A. Memon, A. Laghari, N. Jalbani, and J. Strait, "Techno-economic analysis of solar pv electricity supply to rural areas of balochistan, pakistan," Energies, vol. 11. DOI: 10.3390/en11071777

[22] A. Ghafoor and A. Munir, "Design and economics analysis of an off-grid pv system for household electrification," Renewable and Sustainable Energy Reviews, vol. 42, p. 496-502. DOI: 10.1016/j .rser . 2014. 10.012

[23] G. Merei, C. Berger, and D. Sauer, "Optimization of an off-grid hybrid pv-wind-diesel system with different battery technologies using genetic algorithm," Solar Energy, vol. 97, p. 460-73. DOI: 10.1016/j . solener . 2013.08 .016

[24] U. R. S, R. S, Q. MU, S. M, and L. A, "Feasibility study of hybrid energy system for off-grid rural electrification in southern pakistan," Energy Exploration and Exploitation, vol. 34, p. 468-82. DOI: 10.1177/ 0144598716630176 
[25] R. Kamal, M. Younas, M. Khalid, and A. Qamar, "Cost optimization of an off-grid hybrid renewable energy system with battery storage for rural electrification in pakistan." Clemson University Power Systems Conference, PSC 20182019.

[26] M. G. Masters and G.M., Renewable and Efficient Electric Power Systems. 676, Canada: John Wiley Sons Inc.

[27] Sullivan, W.G. and EM, Wicks and L.J., "Engineering economy."

[28] A. Brander, A. Sood, C. Wylie, A. Haughton, J. Lovell, and I. Reviewers, "Electricity-specific emission factors for grid electricity," Ecometrica, vol. 2011, p. 1-22.

[29] F. Ahmad and I. Ulfat, "Empirical models for the correlation of monthly average daily global solar radiation with hours of sunshine on a horizontal surface at karachi, pakistan," Turkish Journal of Physics, vol. 28, p. 301-7. DOI: $10.3906 /$ sag-1205-102

[30] L. BY, JR, "The interrelationship and characteristic distribution of direct, diffuse and total solar radiation," Solar Energy, vol. 4, p. 1-9. DOI: 10.1016/0038-092X (60)90062-1

[31] A. Naqvi, A. Ahmed, M. Jamal, A. Majeed, A. Khizar, and B. Shaheer, "Performance evaluation of hybrid pvt air collector . a comparative approach," GMSARN International Journal, vol. 16, p. 121-7.

[32] D. W.-S. MJ, "Energy payback time and carbon footprint of commercial photovoltaic systems," Solar Energy Materials and Solar Cells, vol. 119, p. 296-305. DOI: 10.1016/j . solmat . 2013.08.037

[33] M. Ibrahim, N. Mostafa, A. Osman, and A. Hesham, "Performance analysis of a stand-alone hybrid energy system for desalination unit in egypt," Energy Conversion and Management, vol. 215, no. 112941. DOI: 10 . $1016 / j$. enconman. 2020.112941 